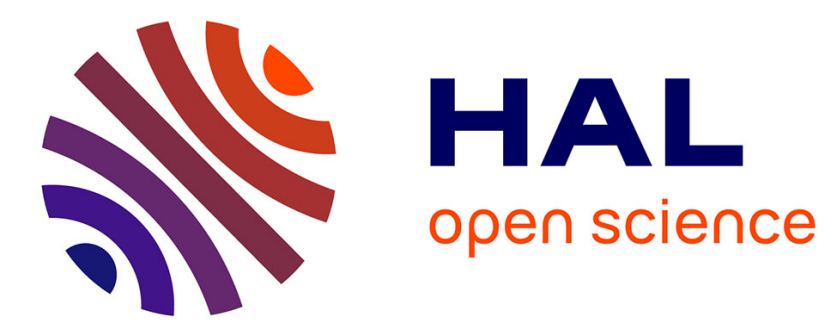

\title{
Allergic contact dermatitis caused by methylisothiazolinone in hair gel
}

Antoine Badaoui, Olivier Bayrou, Charlotte Fite, Camille Frances, Angele

Soria, Catherine C. Pecquet

\section{- To cite this version:}

Antoine Badaoui, Olivier Bayrou, Charlotte Fite, Camille Frances, Angele Soria, et al.. Allergic contact dermatitis caused by methylisothiazolinone in hair gel. Contact Dermatitis, 2015, 73 (6), pp.364-366. 10.1111/cod.12467 . hal-01241319

\section{HAL Id: hal-01241319 https://hal.sorbonne-universite.fr/hal-01241319}

Submitted on 10 Dec 2015

HAL is a multi-disciplinary open access archive for the deposit and dissemination of scientific research documents, whether they are published or not. The documents may come from teaching and research institutions in France or abroad, or from public or private research centers.
L'archive ouverte pluridisciplinaire HAL, est destinée au dépôt et à la diffusion de documents scientifiques de niveau recherche, publiés ou non, émanant des établissements d'enseignement et de recherche français ou étrangers, des laboratoires publics ou privés. 


\section{$1 \quad$ Allergic contact dermatitis to methylisothiazolinone in hair gel}

2 A. Badaoui, $\mathrm{MD}^{1}$, O. Bayrou, $\mathrm{MD}^{1}$, C. Fite, $\mathrm{MD}^{2}$, C. Frances, $\mathrm{MD}^{1}$, A. Soria, MD, $\mathrm{PhD}^{1,3}, \mathrm{C}$. 3 Pecquet, $\mathrm{MD}^{1}$.

$4 \quad{ }^{1}$ Dermatologie-Allergologie, Hôpital Tenon, 4 rue de la Chine 75020 Paris HUEP, APHP

$5 \quad{ }^{2}$ Dermatologie, Hôpital Bichat, 46 rue Henri Huchard 75018 Paris, APHP

$6 \quad{ }^{3}$ Sorbonne Universités, UPMC Univ Paris 06, Unité Mixte de Recherche de Santé (UMR S)

7 CR7,Centre d'Immunologie et des Maladies Infectieuses - Paris (Cimi-Paris), F-75013, Paris,

8 France; Institut National de Santé et de Recherche Médicale (INSERM) U1135, Cimi-Paris,

$9 \quad$ F-75013, Paris, France

\section{Name of Institutions:}

${ }^{1}$ Department of Dermatology and Allergology, Tenon Hospital

${ }^{2}$ Sorbonne University, UPMC Univ Paris 06, Unité UMR S CR7, Immunology and Infectious diseases Center - Paris (Cimi-Paris), F-75013, Paris, France; INSERM U1135, Cimi-Paris, F75013, Paris, France

\section{Correspondance and reprint request:}

Dr Antoine Badaoui, Service de Dermatologie-Allergologie, Hôpital Tenon, Assistance Publique-Hôpitaux de Paris et Université Paris VI. 4, rue de la Chine 75020 Paris. Tel: +33156017227; Fax: +33156017235; email: mailto: abadaoui92@hotmail.com

Conflict of interest: none.

Funding: none

All authors participated in the writing of this manuscript. 


\section{Summary}

Introduction: Over the past few years, allergic contact dermatitis to MI has reached an epidemic level in Europe. We report a series of 4 patients presenting allergic contact dermatitis of the face and/or the scalp secondary to the use of hair gel containing MI. Patients: This retrospective study included all patients who presented facial contact dermatitis due to hair gel between October 2014 and March 2015. Four non atopic patients (3 male, 1 female) presented facial dermatitis, not improving despite avoidance of shampoo and/or facial cosmetics containing MI, with positive MI and MCI/MI patch test in all cases. Hair gels were secondary suspected because the persistence of contact dermatitis despite the avoidance of all previously suspected products.

Discussion: Allergic contact dermatitis to hair gel has been rarely reported yet in literature. Diagnosis of our cases was difficult since none of our patients reported spontaneously using hair gel. Indeed, according to them, hair gel could not be responsible for contact dermatitis since it was not applied on the skin. Dermatologist and allergologist should think about hair gel when facing an eczematiform rash of the face and/or the scalp.

Key words: allergic contact dermatitis, eczema, methylisothiazolinone, hair gel, cosmetic. 


\section{INTRODUCTION}

Methylisothiazolinone (MI; CAS no. 2682-20-4) has been used alone or in association with methylchloroisothiazolinone (MCI) in the mixture MCI/MI 3/1.The maximum authorized concentration of MI in cosmetics, whether rinse-off or not, is $100 \mathrm{ppm}$ in Europe and in the United States (1). Over the past few years, allergic contact dermatitis to MI has reached an epidemic level in Europe (2). We report a series of 4 patients presenting allergic contact dermatitis of the face and/or the scalp secondary to the use of hair gel containing MI. These cosmetics are not usually known to cause allergic reactions.

\section{PATIENTS AND METHODS}

This retrospective study included all patients who presented facial contact dermatitis due to hair gel between October 2014 and March 2015 in the department of dermatology and allergology, Tenon Hospital, Paris. All patients were tested with the European Baseline and Cosmetic Series of patch test (MI alone $2000 \mathrm{ppm}$ and MI/MCI 100 and $200 \mathrm{ppm}$ (Chemotechnique, Vellinge, Sweden) and reading was performed at day 2 (D2) and D4, according to the International Contact Dermatitis Research Group criteria for readings (3). When possible, topical products incriminated were also tested by semi-open test or repeating open application tests (ROAT).

\section{Cases 1 to 4}

Four non atopic patients presented facial dermatitis (figure 1), not improving despite avoidance of shampoo and/or facial cosmetics containing MI, with positive MI and MCI/MI patch test in all cases. Hair gels were secondary suspected because the persistence of contact dermatitis despite the avoidance of all previously suspected products, and after having reexamined all patients. Among these patients, 3 were male and 1 was female, they were aged 
between 40 and 56 years old (mean age 49.8 years-old). Physical examination and allergologic skin tests were summarized Table 1.

\section{DISCUSSION}

We report 4 new patients presenting allergic contact dermatitis of the scalp and/or the face due to MI. These cases are original since they are secondary to the use of hair gel, which, to our knowledge, has been rarely reported yet. Indeed, all other publications reported allergic contact dermatitis to MI contained in hair cosmetic, without specifically referring to hair gel. In literature, only two cases of allergic contact dermatitis to hair gel were published: the first case was a 12-year-old boy who presented an inflammatory rash after using a hair gel; patch tests were positive to copolymer PVP/1-triacontene, contained in hair gel (4); the second case was a 42-year-old male who presented a severe acute eczematous rash of the face, ears and neck after using hair gel (5). Patch tests were positive for diazolidinyl urea, contained in hair gel. Semi-open tests were positive for the hair gel.

Besides, diagnosis of our cases was difficult since none of our patients reported spontaneously using hair gel. Indeed, all of them reported using different brands of shampoo or make-up, which did not contain MI, but, according to them, hair gel could not be responsible for contact dermatitis since it was only applied on hair and not directly on the skin. Three of our patients were male, which is consistent with the usual use of hair gel in France.

Hair gels were of 3 different brands and all of them contained MI. Patch tests for MI and MI/MCI were positive in all our patients. Semi-open test and ROAT with hair gel were positive in the only patient tested with his hair gel. Unfortunately, we do not know the concentration of MI in all of these products. 
Prevalence of allergic contact dermatitis to MI has increased in Europe over the past few years. Indeed, in Denmark, Schwensen et al (6) reported a significant increase in the prevalence of allergic contact dermatitis to MI from $1.8 \%$ in 2009 to $4.2 \%$ in 2012. In France as well, Hosteing and the REVIDAL-GERDA reported a significant increase in the frequency of positive patch test to MI from $1.5 \%$ in 2010 to $5.6 \%$ in 2012 (7). This positivity was relevant with the clinical history in $90 \%$ of cases.

Besides, de Unamuno (8) noticed the face was the third most common site involved in allergic contact dermatitis to MI/MCI whereas, in the Belgian cohort, Aerts et al (2) reported the face was the most affected site in allergic contact dermatitis to MI.

To conclude, we report four cases of facial and scalp allergic contact dermatitis to MI due to hair gel, a very common cosmetic. We would like to emphasize the fact that none of our patients reported spontaneously using hair gel since, according to them, it could not be the culprit. Dermatologist and allergologist should think about hair gel when facing an eczematiform rash of the face and/or the scalp. 
1. Burnett CL, Bergfeld WF, Belsito DV, Klaassen CD, Marks JG Jr, Shank RC, Slaga TJ, Snyder PW, Alan Andersen F. Final report of the safety assessment of methylisothiazolinone. Int J Toxicol. 2010 Jul;29. 187S-213S.

2. Aerts O, Baeck M, Constandt L, Dezfoulian B, Jacobs MC, Kerre S, Lapeere H, Pierret L, Wouters K, Goossens A. The dramatic increase in the rate of methylisothiazolinone contact allergy in Belgium: a multicentre study. Contact Dermatitis. 2014 Jul;71(1):41-8.

3. Wilkinson DS, Fregert S, Magnusson B. Terminology of contact dermatitis. Acta Derm Venereol. 1970;50:287-292.

4. Kai A., Khorshid M., McFadden J. Allergic contact dermatitis to copolymers. British Journal of Dermatology 2010163 Suppl. 1 (87)

5. Kantor GR, Taylor JS, Ratz JL, Evey PL. Acute allergic contact dermatitis from diazolidinyl urea (Germall II) in a hair gel. J Am Acad Dermatol. 1985 Jul;13(1):116-9.

6. Schwensen JF, Menné T, Andersen KE, Sommerlund M, Johansen JD. Occupations at risk of developing contact allergy to isothiazolinones in Danish contact dermatitis patients: results from a Danish multicentre study (2009-2012). Contact Dermatitis. 2014 Nov;71(5):295-302.

7. Hosteing S, Meyer N, Waton J, Barbaud A, Bourrain JL, et al; REVIDAL-GERDA network. Outbreak of contact sensitization to methylisothiazolinone: an analysis of French data from the REVIDAL-GERDA network. Contact Dermatitis. 2014 May;70(5):262-9. 
8. de Unamuno B, Zaragoza Ninet V, Sierra C, de la Cuadra J. Descriptive study of sensitization to methylchloroisothiazolinone and methylisothiazolinone in a skin allergy unit. Actas Dermosifiliogr. 2014 Nov;105(9):854-9. 
130 TABLES

131 Table 1: Clinical presentations and results of allergologic skin tests for allergic dermatitis due 132 to contact with methylisothiazolinone.

133 ROAT: Repeated Open Application Tests, F: female, M: male. MI: methylisothiazolinone, MCI: methyl-Chloro134 isothiazolinone.

135

136 FIGURES

137 Figure 1: Erythematous and squamous rash of the ear. 


\begin{tabular}{|c|c|c|c|}
\hline Cases & Sex/Age & Product used & Duration \\
\hline 1 & $\mathrm{M} / 56$ & Hair gel & 4 months \\
\hline 2 & $\mathrm{~F} / 50$ & $\begin{array}{l}\text { One standard } \\
\text { shampoo, another } \\
\text { shampoo for } \\
\text { damaged hair and } \\
\text { hair gel }\end{array}$ & 24 months \\
\hline
\end{tabular}

3

M/53 Hair gel 12 months

$4 \mathrm{M} / 40$
Hair gel

Unknown

\section{Physical examination}

Erythematous and oozing

lesions of the forehead and the anterior part of the scalp

Erythematous and oedematous

lesions of the upper eyelid

Erythematous and lichenified lesions of the neck, edge of the scalp, and helix (figure 1)

Papular erythematous lesions of the forehead and both sides of the neck.

\section{Allergologic skin tests (D2, D4)}

\section{Patch tests:}

MI ++/++, MI/MCI 200ppm

$++/++$

Semi-open test hair gel $+/+$ ROAT hair gel ++ (D1)

\section{Patch tests:}

MI ++/++, MI/MCI 200ppm

$++/++$

All personal product - (hair gel was not tested)

\section{Patch tests:}

MI ++/++, MI/MCI 200ppm $++/++$ and DMDM hydantoin $+/++$

\section{Patch tests:}

$\mathrm{MI}+++/+++, \mathrm{MI} / \mathrm{MCI}$

200ppm+++/+++

\section{Clinical relevance}

MI contained in hair gel

MI contained in hair gel

MI contained in hair gel

MI contained in hair gel
Evolution after allergen avoidance

No recurrence

No recurrence

Lost to follow up

No recurrence 